\title{
Spatial and temporal evolutions of groundwater arsenic approxi- mately along the flow path in the Hetao basin, Inner Mongolia
}

\author{
GUO HuaMing ${ }^{1,2^{*}}$, ZHANG Yang $^{2}$, JIA YongFeng ${ }^{1,2}$, ZHAO Kai $^{1,2} \& \mathrm{KIM} \mathrm{Kangjoo}^{3}$ \\ ${ }^{1}$ State Key Laboratory of Biogeology and Environmental Geology, China University of Geosciences, Beijing 100083, China; \\ ${ }^{2}$ School of Water Resources and Environment, China University of Geosciences, Beijing 100083, China; \\ ${ }^{3}$ Department of Environmental Engineering, Kunsan National University, Jeonbuk 573-701, Republic of Korea
}

Received June 25, 2012; accepted October 8, 2012; published online March 29, 2013

\begin{abstract}
Patchy distribution of high As groundwater has normally been observed in As-affected areas. Spatial and temporal evolutions help in better understanding mechanisms of As mobilization and in developing effective strategies for ensuring drinking water safety. Four multilevel samplers were installed approximately along the groundwater flow path to investigate spatial and temporal variations in groundwater As in the Hetao basin, Inner Mongolia. Both water chemistry and groundwater level were monitored for about two years. Groundwater As concentration generally showed increasing trends, and Eh values showed decreasing trends along the flow path, indicating that As was mobilized via reductive dissolution of Fe oxides. However, in evaporation discharge area, shallow groundwater As was generally lower than those upstream and downstream. In addition to evaporation, siderite and pyrite precipitations controlled groundwater As concentrations. The negative correlations between As concentration and $\mathrm{SI}_{\text {pyrite }}($ or $\mathrm{SI}_{\text {siderite }}$ ) implied that siderite and pyrite precipitations would scavenge groundwater As and lower As concentration. Temporal variation showed different trends in different locations. It may reflect replenishment of high/low As groundwater for the increase/decrease in As concentrations, resulting from water level fluctuation. The increase trends in groundwater As concentrations at depth around $15 \mathrm{~m}$ in the discharge areas would result from the increase in the recharge of underlying groundwater $(20 \mathrm{~m})$ with high As concentration due to enhanced evaporation in the seasons with high water levels. The investigation suggested that monitoring of groundwater As should be routinely carried out to ensure the drinking water safety in the As-affected areas.
\end{abstract}

aquifer, water-rock interaction, hydrogeochemistry, As species, evaporation

Citation: Guo H M, Zhang Y, Jia Y F, et al. Spatial and temporal evolutions of groundwater arsenic approximately along the flow path in the Hetao basin, Inner Mongolia. Chin Sci Bull, 2013, 58: 3070-3079, doi: 10.1007/s11434-013-5773-7

High As groundwater has posed a significant health impact on thousands of millions of people [1], which has received much concern from scientific community and management agencies [2-5]. Many investigations have shown that groundwater As is highly variable at both local and regional scale in reducing aquifers from river deltas (including Red River delta, Mekong delta, Ganges delta, Yellow river delta, Pearl River delta, etc.) [4,5] and inland basins (including the Hetao basin, the Datong basin, the Yinchuan basin, the west Jilin basin, and the Zhunger basin, etc.) [6-11]. Groundwater As concentrations span three orders of magnitude over distances from tens of meters to kilometers [6,12-15]. The

*Corresponding author (email: hmguo@cugb.edu.cn) causes of the lateral heterogeneity in As concentration are diverse, including recharge of human-derived dissolved organic carbon (DOC) $[4,16]$, distribution of natural organic matter $[17,18]$, distribution of surface geologic conditions [8,19-21], surface water-groundwater interaction [7], distribution of paleaosol layers [22-24], groundwater flushing [26,27], and recharge rate [20,25]. The patchy distribution of groundwater As makes it difficult to get safe drinking water in As-affected areas. It is necessary to reveal the pattern and the causes of groundwater As distribution in order to locate drinking water wells in low As groundwater aquifers.

Such spatial variability in As concentration is expected to lead to temporal variation of As concentration. The tem- 
poral variation in As concentration is also related to the fluctuation of water tables. The lowest As and P concentrations, and the highest major cation, S, and Mn concentrations, were observed in shallow groundwater during the dry season in some wells in Bangladesh [28]. In West Bengal, a decrease in As concentration was found during high groundwater level season [29]. In the Hetao basin and the Yinchuan basin, limited data showed the higher As concentrations in November with the higher groundwater levels in comparison with in July [11]. This increase trend would increase the exposure of well users to excessive As without their knowledge. The temporal variation would be related to recharge of surface water $[4,11]$, replenishment with high/ low-arsenic groundwater [30,31], and flushing [32]. Therefore, it is crucial to characterize spatial and temporal variations in groundwater As to better understand the mechanisms of As cycling and to help in developing effective strategies for ensuring drinking water safety in As-affected areas.

The Hetao basin is a typical inland basin hosting high As groundwater in shallow aquifers [7]. The spatial distribution of groundwater As has been investigated, showing that high As groundwaters generally occurred in shallow alluviallacustrine aquifers [6]. Groundwater As was believed to originate from exchangeable As and Fe/Mn oxide-binding As in the aquifer sediments [6], which was confirmed by microcosm study of intact aquifer sediments in the lab [33]. Groundwater As would be more likely associated with small-size organic colloids than Fe colloids [34], which indicated controls of organic colloids on As concentration. Furthermore, both hydrogeology and biogeochemistry constrained As mobilization, leading to occurrence of low As groundwater near the irrigation channels and the drainage channels [7]. Distribution of As in shallow groundwaters was highly patchy on a local or regional scale both vertically and horizontally [8]. Previous investigation showed that there were no significant changes in As concentration between 2006 and 2010, although shallow groundwaters sampled in November from the flat plain region with surface water irrigation generally had higher As concentrations than in July [11]. However, high-resolution monitoring data are not available for revealing temporal variation in groundwater As in the Hetao basin.

The major objectives are to (1) characterize spatial variation in groundwater As both vertically and horizontally along the flow path, (2) investigate temporal variations in groundwater As at different depths of shallow aquifers, and (3) evaluate hydrogeochemical processes controlling groundwater As concentrations.

\section{Materials and methods}

\subsection{Water sampling}

The Hetao basin is located in the west of Inner Mongolia, locally to the north of the Yellow River, to the east of the Wuranbuh Desert, and to the south border of Langshan Mountains (Figure 1). Detailed description of local geological and hydrogeological settings can be found in Guo et al. $[6,7]$. Shallow groundwater mainly occurs in the Quaternary alluvial, alluvial-pluvial, and fluvial-lacustrine aquifers, which are unconfined or leaky-confined. The shallow groundwater flow system has been affected by irrigation channels and drainage channels in most of the study area, as well as irrigation practices on the farmlands. In the basin, the average annual precipitation is around $188 \mathrm{~mm}$, which is much less than potential evaporation of 2000 to $2500 \mathrm{~mm}$ [8].

Four multilevel samplers were installed in the Shahai town, approximately along the groundwater flow path (Figure 1(a)). One is located in the area with groundwater for irrigation (BH01), the other three in the areas with diverted Yellow River water for irrigation (BH02, BH03 and BH04). Installation and layout the samplers and lithologic settings have been provided in Guo et al. [8]. Groundwater levels were monitored using water level data loggers (HOBO U20, Onset) at the four locations. Groundwater sampling was carried out ten times from these samplers from May 2010 to April 2012 (usually once a month, except for the winter season). Groundwater was sampled from each sampler after pumping for more than $20 \mathrm{~min}$ until water temperature, electrical conductivity (Ec), $\mathrm{pH}$, and Eh were stable. At the time of groundwater sampling, parameters, including water temperature, Ec, pH, and Eh, were measured using a multiparameter portable meter (HANNA, HI 9828), while concentrations of $\mathrm{NH}_{4}^{+}, \mathrm{S}^{2-}$, and $\mathrm{Fe}$ (II) were determined by using a portable spectrophotometer (HACH, DR2800). Alkalinity was determined at the time of sampling by using a Model 16900 digital titrator (HACH) using bromocresol green-methyl red indicator. All of samples were filtered through $0.45 \mu \mathrm{m}$ membrane filters in the field for analysis in the laboratory. The samples for major and trace element analysis were acidified to $\mathrm{pH} 1$ using $6 \mathrm{~mol} / \mathrm{L} \mathrm{HNO}_{3}$. Those for analysis of As species were preserved with $0.25 \mathrm{~mol} / \mathrm{L}$ EDTA in amber bottles [35]. Samples for anion analysis were filtered but unacidified. Those for analysis of $\delta^{18} \mathrm{O}$ and $\delta \mathrm{D}$ were collected in $100 \mathrm{~mL} \mathrm{HNO}_{3}$-washed polyethylene bottles with airtight caps with no headspace without filtration. All samples were stored at $4^{\circ} \mathrm{C}$ in a refrigerator after sampling.

\subsection{Analysis}

Concentrations of major cations and trace elements were determined by inductively coupled plasma atomic emission spectroscopy (ICP-AES) and inductively coupled plasma mass spectroscopy (ICP-MS), respectively. Unacidified aliquots were analyzed for $\mathrm{Cl}^{-}, \mathrm{NO}_{3}^{-}, \mathrm{SO}_{4}^{2-}$ by Ion Chromatography with an instrument model DX-120 (Dionex). In most cases, analytical charge imbalances were less than $5 \%$. 

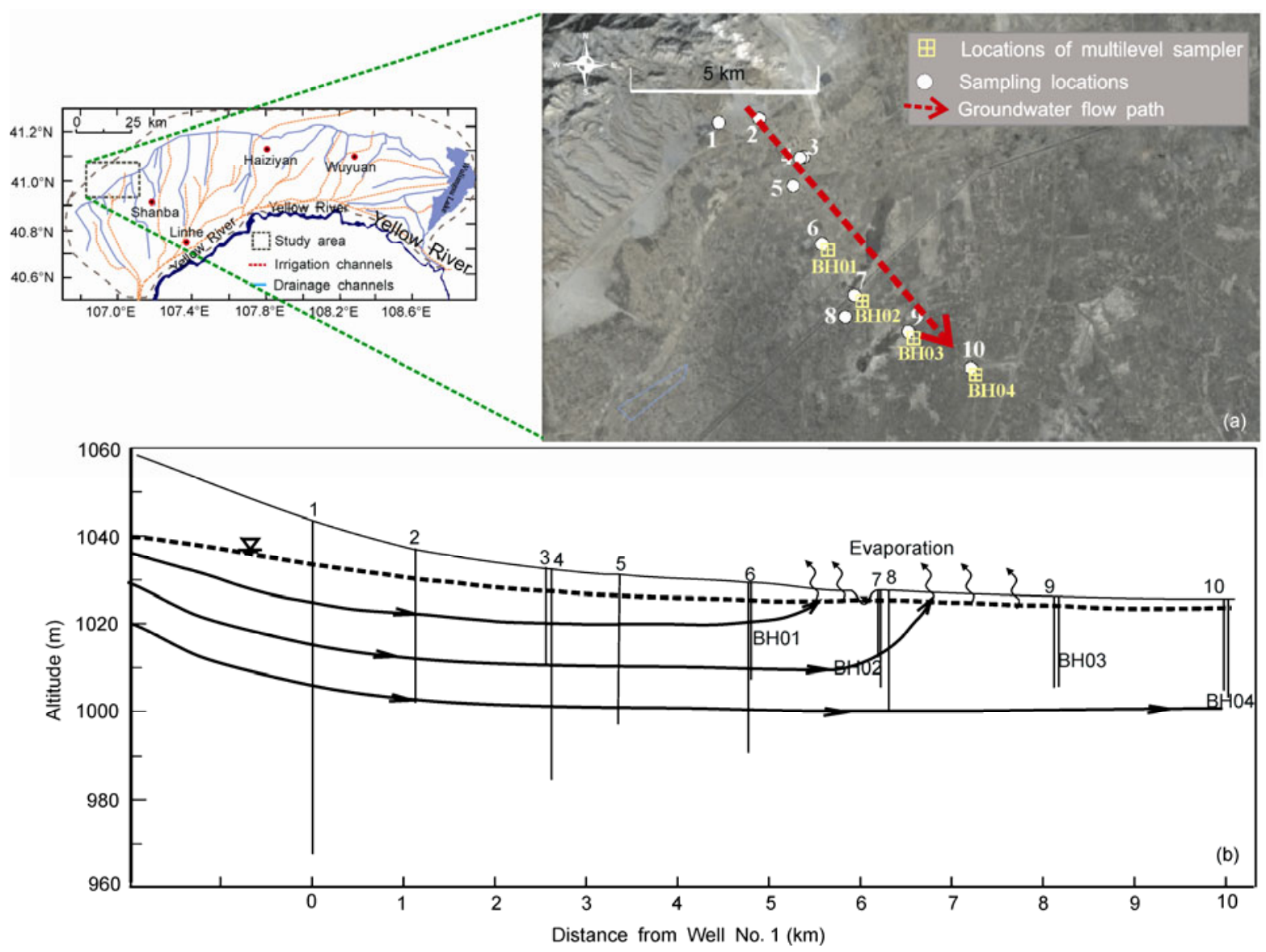

Figure 1 Location of multilevel samplers (a) and simple hydrogeologic profile approximately along the groundwater flow path (b) in the study area.

Arsenic species in groundwater samples were analyzed using high performance liquid chromatography (HPLC)ICP-MS [34].

Oxygen and hydrogen isotope compositions were determined using standard methods for waters by MAT253 (Finnigan). Analytical precisions of $\delta^{18} \mathrm{O}$ and $\delta \mathrm{D}$ were $\pm 0.1 \%$ 。 and $\pm 1 \%$, respectively, and expressed relative to the SMOW.

\section{Results}

\subsection{Variations in water levels}

Groundwater levels showed great variations in the study area, depending on irrigation practice and hydrogeological settings. Near the alluvial fans, the depth of water level (between 3.5 and $8.0 \mathrm{~m}$ below land surface (BLS)) was generally greater than that in the flat plain (between 0.5 and $2.8 \mathrm{~m}$ BLS) (Figure 2). Observation data showed two patterns of temporal variation in groundwater levels. The BH01 near the alluvial fans, where groundwater was used for irrigation, showed a great fluctuation in water levels. In BH01, water level drastically declined from 4.0 to $8.0 \mathrm{~m}$ BLS from April to June (summer irrigation), with a second decrease in November (winter irrigation). The groundwater level fluctuated between 5.0 and $7.8 \mathrm{~m}$ BLS due to limited recharge of precipitation and follow-up irrigation (from June to August). As soon as the irrigation ceased, the water level rose from November to December. The groundwater table stabilized at around 4.0 m BLS during winter season (from December to April) without irrigation (Figure 2(a)).

In the flat plain with surface water irrigation, where $\mathrm{BH} 02, \mathrm{~B} 03$ and $\mathrm{BH} 04$ are located, groundwater levels slightly fluctuated (Figure 2(b)-(d)). Water levels were generally lower between November and March (during the winter) and between September and October, during which no irrigation was carried out, while during irrigation seasons (summer irrigation between April and September and winter irrigation in November) they were generally higher. Fluctuation in water levels associated with the irrigation practice indicated the recharge of surface water into groundwater. Since the precipitation is very low in the study area, the groundwater level was less affected by the precipitation.

\subsection{Spatial variations in groundwater chemistry along the flow path}

Fourteen locations along the flow path from the alluvial fan to the flat plain were selected to evaluate chemical evolution, including nine reported in Guo et al. [7], one taken in 

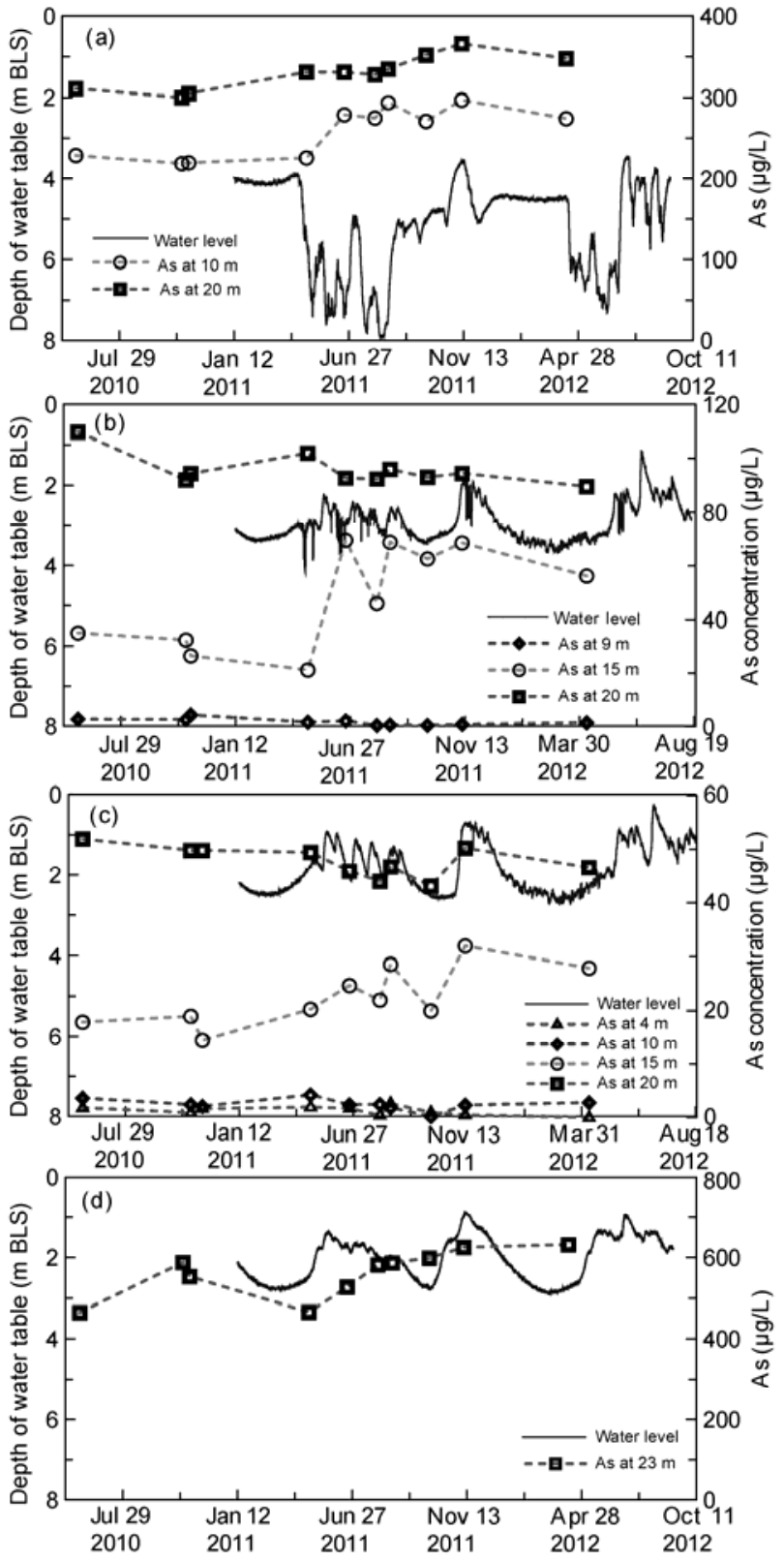

Figure 2 Temporal variations in water level and As concentrations of groundwater from BH01 (a), BH02 (b), BH03 (c), and BH04 (d).

May 2010, and four of multilevel samplers (Figure 1 and Table 1). The hydrogeological profile along the flow path is shown in Figure 1(b). Physiochemical parameters at the locations of multilevel samplers were the averages of monitoring data for groundwater samples taken at the depth around $20 \mathrm{~m}$ for ten times in this study.

Groundwater showed variations in physiochemical parameters along the flow path (Figure 3). Near the recharge area (the alluvial fan), groundwater had low TDS concentration (mostly $<500 \mathrm{mg} / \mathrm{L}$ ). However, TDS, $\mathrm{Cl}^{-}$concentrations and $\delta^{18} \mathrm{O}$ values were high in evaporation discharge area in the flat plain (between Well No.7 and BH03). In the down-gradient of $\mathrm{BH} 03$, groundwater had relatively low
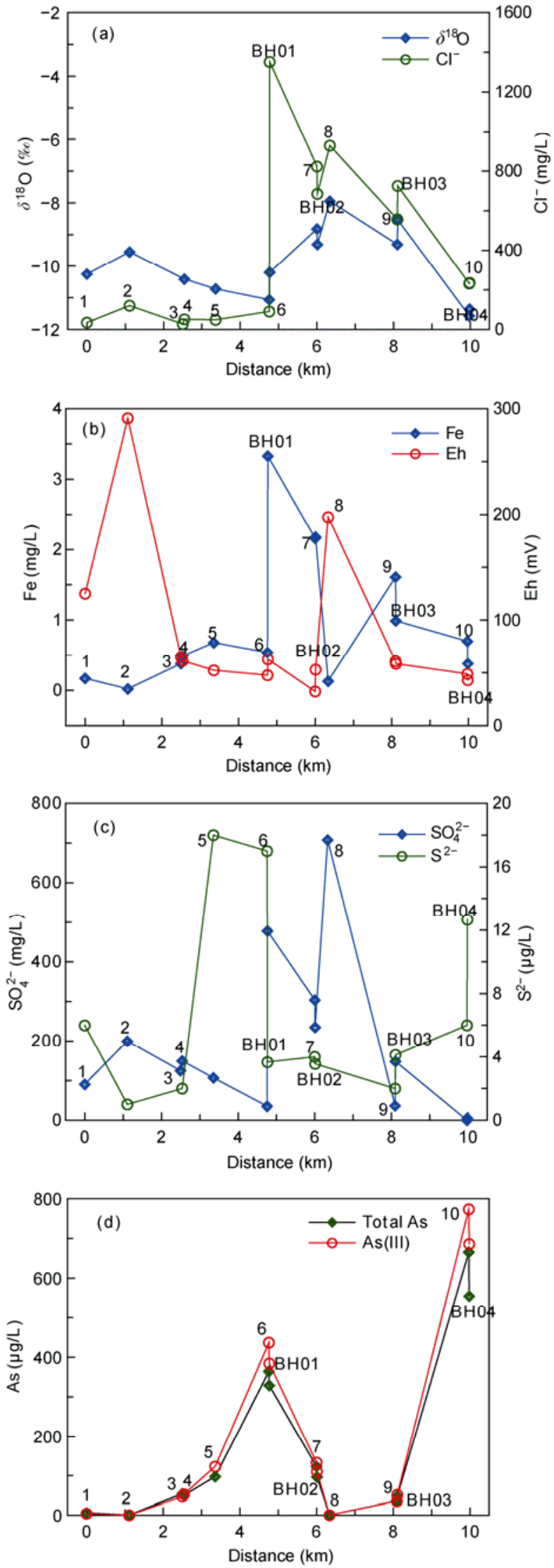

Figure 3 Chemical and isotopic variations of groundwater approximately along the flow path (shown in Figure 1). 


\begin{tabular}{|c|c|c|c|c|c|c|c|c|c|c|c|c|c|c|c|}
\hline 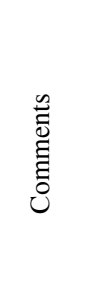 & 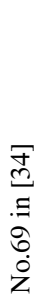 & $\begin{array}{l}\underset{d}{d} \\
. \\
0 \\
0 \\
\dot{0} \\
\dot{z}\end{array}$ & 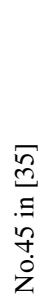 & 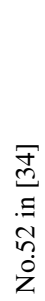 & 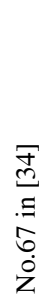 & $\begin{array}{l}F \\
\stackrel{0}{0} \\
\stackrel{\Xi}{0} \\
\dot{0} \\
\dot{z}\end{array}$ & 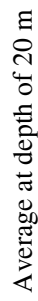 & 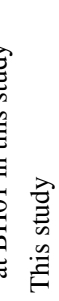 & & 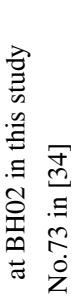 & 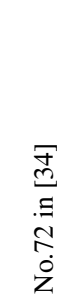 & & 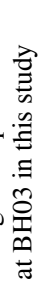 & 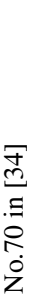 & 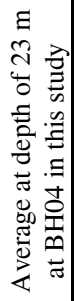 \\
\hline 80 & $\stackrel{i}{i}$ & $?$ & । & $\hat{\imath}$ & $\hat{\imath}$ & $\stackrel{\infty}{\infty}$ & † & ț & $\stackrel{t}{T}$ & $\hat{i}$ & $\stackrel{n}{i}$ & $\tilde{\tau}$ & & $\widehat{\infty}_{1}$ & $\mathscr{p}_{1}$ \\
\hline$\underset{\infty}{\infty} \stackrel{\infty}{\infty}$ & $\frac{m}{1}$ & $\stackrel{\circ}{i}$ & I & $\stackrel{+}{\stackrel{1}{1}}$ & $\stackrel{\hat{0}}{1}$ & 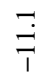 & $\stackrel{1}{1}$ & $\begin{array}{c}\infty \\
\infty \\
i \\
i\end{array}$ & i & 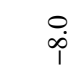 & $\stackrel{m}{i}$ & 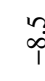 & & 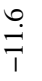 & $\stackrel{+}{=}$ \\
\hline 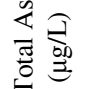 & $\overline{6}$ & $\stackrel{t}{0}$ & İ & iि & $\begin{array}{l}n \\
\vdots \\
\vdots \\
a\end{array}$ & 总 & ले & 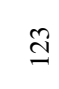 & 童 & $\stackrel{t}{0}$ & ले & चे & & 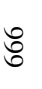 & 古 \\
\hline 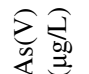 & 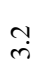 & $\stackrel{0}{\vec{v}}$ & $\overline{9}$ & $\stackrel{+}{\varrho}$ & $\vec{n}$ & 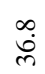 & तi & $\tilde{\pi}$ & vn & $\stackrel{\circ}{\vec{v}}$ & $\stackrel{\nabla}{\sigma}$ & $\infty$ & & $\begin{array}{c}\dot{*} \\
\infty \\
\infty\end{array}$ & $\stackrel{\text { m. }}{m}$ \\
\hline 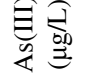 & $\hat{i}$ & $\stackrel{\circ}{\vec{v}}$ & 굴 & $\hat{\text { ले }}$ & ji & స్ & $\infty$ & बें & $\tilde{\infty}$ & $\stackrel{\circ}{\vec{v}}$ & ñ & $\begin{array}{l}\infty \\
\infty \\
\infty \\
\infty\end{array}$ & & $\stackrel{8}{\circ}$ & $\frac{n}{n}$ \\
\hline 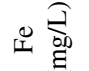 & †. & $\stackrel{\delta}{\circ}$ & $\stackrel{\infty}{0}$ & $\stackrel{g}{0}$ & $\stackrel{\infty}{0}$ & in & $\stackrel{m}{m}$ & $\underset{\sim}{\stackrel{0}{i}}$ & $\frac{\infty}{\lambda}$ & $\frac{9}{0}$ & $\underset{-}{\vec{\sigma}}$ & : & & 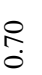 & 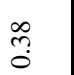 \\
\hline 苞 & $\vec{a}$ & $\stackrel{8}{0}$ & $\begin{array}{l}\stackrel{\circ}{g} \\
\dot{q}\end{array}$ & $\stackrel{9}{i}$ & $\stackrel{m}{\curvearrowright}$ & m. & $\stackrel{2}{\beth}$ & $\hat{\text { gे }}$ & $\frac{n}{a}$ & 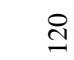 & $\vec{m}$ & ت & & $\stackrel{\dot{\theta}}{\dot{\theta}}$ & fi \\
\hline 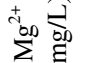 & ن. & $\begin{array}{l}n \\
b\end{array}$ & $\stackrel{\overbrace{}}{\Xi}$ & $\hat{\mathrm{d}}$ & $\stackrel{\sim}{\mathrm{N}}$ & $\hat{\dot{m}}$ & $\stackrel{\infty}{\infty}$ & ది & $\stackrel{\infty}{\Xi}$ & $\underset{\sim}{\infty}$ & t & $\stackrel{2}{\Sigma}$ & & $\stackrel{\circ}{\vec{\lambda}}$ & लें \\
\hline 㐒 & $\stackrel{i}{m}$ & $\stackrel{\partial}{\infty}$ & $\stackrel{n}{j}$ & है & $\begin{array}{l}\infty \\
\stackrel{\mathbf{d}}{ }\end{array}$ & $\stackrel{n}{q}$ & $\widehat{\infty}$ & 古 & sq & $\stackrel{ }{1}$ & ฉ̊ & శ్రి & & $\frac{t}{m}$ & ळे \\
\hline 老命 & $\stackrel{\infty}{\tilde{i}}$ & $\underset{+}{\stackrel{8}{+}}$ & $\overrightarrow{\dot{f}}$ & $\stackrel{m}{m}$ & $\overrightarrow{\mathcal{N}}$ & $\stackrel{m}{m}$ & $\stackrel{\text { ते }}{2}$ & $\stackrel{?}{2}$ & $\stackrel{n}{ \pm}$ & ల్ల & $\stackrel{7}{n}$ & 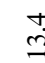 & & هे & $\stackrel{\infty}{\stackrel{\infty}{\sim}}$ \\
\hline$\underset{D}{\stackrel{O}{b D}}$ & $\Xi$ & ర్రి & $\Xi$ & $\stackrel{\sim}{\sim}$ & $\stackrel{\Delta}{\sim}$ & ते & $\hat{\Sigma}$ & $\stackrel{\sim}{\sim}$ & $\tilde{g}$ & $\stackrel{\infty}{2}$ & f & ? & & $\tilde{\sigma}$ & ఫ్రి \\
\hline $\begin{array}{ll}1+t \\
\text { ô }\end{array}$ & $\begin{array}{l}0 \\
\dot{\alpha}\end{array}$ & $\underset{\sim}{~}$ & $\stackrel{\beth}{\beth}$ & $\stackrel{8}{n}$ & 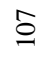 & $\begin{array}{l}n \\
n \\
m\end{array}$ & $\stackrel{\infty}{f}$ & 总 & $\ddot{n}$ & $\stackrel{\infty}{R}$ & 㐫 & $\stackrel{\infty}{\mathfrak{I}}$ & & ¿े. & $\stackrel{i}{n}$ \\
\hline 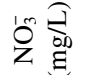 & $\begin{array}{l}\overline{\vec{b}} \\
\dot{\vec{v}}\end{array}$ & $\stackrel{8}{0}$ & $\begin{array}{l}\overrightarrow{\dot{v}} \\
\stackrel{\mathrm{v}}{ }\end{array}$ & $\stackrel{\circ}{-}$ & $\stackrel{\sim}{+}$ & $\hat{b}$ & $\stackrel{g}{\dot{I}}$ & $\begin{array}{l}\overrightarrow{0} \\
\dot{\mathrm{v}}\end{array}$ & $\stackrel{0}{\circ}$ & $\begin{array}{l}\overrightarrow{\dot{v}} \\
\dot{\mathrm{v}}\end{array}$ & $\vec{i}$ & 2 & & $\begin{array}{l}\vec{\vdots} \\
\stackrel{\dot{v}}{v}\end{array}$ & $\stackrel{\bullet}{\sim}$ \\
\hline 它 & $\dot{m}$ & 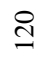 & $\stackrel{+}{\stackrel{\sim}{\sim}}$ & $\stackrel{n}{i n}$ & 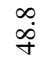 & $\hat{g}$ & ch & तి & 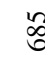 & ๙ે & in & $\ddot{\tilde{z}}$ & & స్ & ஜ্ণ \\
\hline 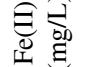 & oे. & $\delta_{0}^{\circ}$ & । & $\vec{m}$ & f & กู & 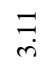 & $\underset{\text { i }}{\stackrel{i}{~}}$ & $\stackrel{+\infty}{-\infty}$ & $\stackrel{\overbrace{}}{8}$ & $\stackrel{\infty}{\text { తి }}$ & : & & ñ. & $\stackrel{0}{0}$ \\
\hline 等 & $\stackrel{0}{0}$ & $\stackrel{\circ}{-}$ & 1 & $\stackrel{\circ}{i}$ & $\stackrel{\infty}{\sim}$ & $=$ & ले & $\stackrel{\circ}{+}$ & rid & 1 & 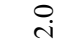 & $\stackrel{8}{q}$ & & : & $\stackrel{2}{2}$ \\
\hline 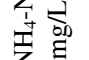 & הี & $\stackrel{n}{\underline{I}}$ & I & $\stackrel{n}{-}$ & $\underset{i}{\stackrel{\circ}{i}}$ & ف & f & $\stackrel{?}{;}$ & ले & $\stackrel{\odot}{\sim}$ & $\stackrel{\rho}{\circ}$ & 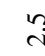 & & $\stackrel{\infty}{\dot{\sim}}$ & $\stackrel{\bullet}{+}$ \\
\hline 讪 $\frac{\sqrt{5}}{2}$ & in & 总 & in & t & ర్రి & $\tilde{i}$ & q & $\frac{8}{m}$ & ถั & $\stackrel{8}{\circ}$ & : & $\frac{尺}{m}$ & & હ્ટ & ڤ્તి \\
\hline 画总 & $\cong$ & $\overline{\mathrm{i}}$ & 8 & $\overrightarrow{6}$ & $\approx$ & $\stackrel{\infty}{q}$ & 8 & $\approx$ & $n$ & $\stackrel{\infty}{\varrho}$ & $\overline{6}$ & in & & g & $\mathscr{q}$ \\
\hline I & $\stackrel{a}{r}$ & $\vec{r}$ & $\stackrel{\stackrel{ }{~}}{\sim}$ & $\stackrel{m}{\infty}$ & $\begin{array}{l}0 \\
\infty\end{array}$ & $\infty$ & $\dddot{?}$ & $\underset{\infty}{\infty}$ & 2 & $\stackrel{a}{r}$ & $\begin{array}{l}0 \\
\infty\end{array}$ & 2 & & $\underset{\infty}{+}$ & ${ }_{\infty}$ \\
\hline 玄总 & 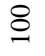 & q & $\vec{\sim}$ & 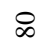 & F & $n$ & ¿ & ¿ & ते & $\stackrel{\sim}{\sim}$ & ¿ & $\stackrel{\sim}{\circ}$ & & 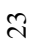 & $\tilde{\lambda}$ \\
\hline 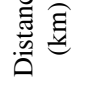 & 0 & $\exists$ & in & 点 & 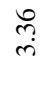 & 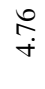 & & $\stackrel{8}{6}$ & $\begin{array}{l}0 \\
0 \\
0\end{array}$ & ले & $\stackrel{\circ}{\circ}$ & ${ }^{\circ}$ & & s. & $\stackrel{\infty}{\circ}$ \\
\hline$z$ & - & $\alpha$ & $m$ & $\theta$ & $n$ & 6 & & r & 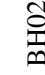 & $\infty$ & $a$ & 饮 & & 우 & 总 \\
\hline
\end{tabular}


TDS and was less affected by evaporation, evidenced by depletion in ${ }^{18} \mathrm{O}$ and low $\mathrm{Cl}^{-}$concentration (Figure 3(a)). In Well No.2, groundwater had higher concentrations of $\mathrm{NO}_{3}^{-}$ $(109 \mathrm{mg} / \mathrm{L})$ and TDS (1070 mg/L) than others in the recharge area, which was possibly influenced by contamination.

Groundwater Eh values generally decreased from the recharge area to Well No.7, with the exception of Well No.1 with the depth of $100 \mathrm{~m}$, and increased in the evaporation area between BH02 and BH03 (Figure 3(b)). With the flow further down gradient, Eh values decreased. Dissolved Fe concentration generally showed opposite trend to Eh value, which increased between Well No.1 and BH01, decreased between BH01 and Well No.8, and increased again between Well Nos.8 and 9. The decreasing trend in Fe concentration between Well No.9 and BH04 would be related to the increase in $\mathrm{S}^{2-}$ concentration in groundwater.

Groundwater showed a decreasing trend in $\mathrm{SO}_{4}^{2-}$ concentration, and an increasing trend in $\mathrm{S}^{2-}$ concentration between Well Nos.2 and 6, possibly indicating the occurrence of $\mathrm{SO}_{4}^{2-}$ reduction. In the evaporation discharge area, $\mathrm{SO}_{4}^{2-}$ concentrations were generally higher, while $\mathrm{S}^{2-}$ concentrations were lower due to relatively higher Eh values. In the down-gradient of Well No.8, groundwater showed a decreasing trend in $\mathrm{SO}_{4}^{2-}$ concentration and an increasing trend in $\mathrm{S}^{2-}$ concentration.

As affected by redox conditions, dissolved $\mathrm{Fe}$ and $\mathrm{S}^{2-}$ concentrations, As concentration varied along the flow path accordingly. Arsenic concentration increased from the recharge area to Well No.6, decreased in the evaporation discharge area. In the down-gradient of Well No.8, it increased again. Arsenic(III) was the major As species. No organic As species were detected in studied groundwater. Variation in As(III) was similar to total As. Arsenic concentration did not show big differences between near neighboring wells ( 50 $\mathrm{m}$ interval), although significant differences were observed in concentrations of $\mathrm{S}^{2-}$ and dissolved Fe (Figure 3).

At the same location, monitoring data of multilevel samplers exhibited the increasing trends in As concentration with increasing the sampling depth (Figure 2). In April 2011, As concentration was $274 \mu \mathrm{g} / \mathrm{L}$ at the depth of $10 \mathrm{~m}$ and $348 \mu \mathrm{g} / \mathrm{L}$ at the depth of $20 \mathrm{~m}$, at BH01. In the evaporation discharge area of $\mathrm{BH} 03$, groundwater had As concentrations of $0.5 \mu \mathrm{g} / \mathrm{L}$ at the depth of $4 \mathrm{~m}$, and $46.6 \mu \mathrm{g} / \mathrm{L}$ at the depth $20 \mathrm{~m}$ in April 2011. Additionally, concentrations of $\mathrm{NH}_{4}-\mathrm{N}$, $\mathrm{Fe}(\mathrm{II})$, and total Fe generally increased with increasing the sampling depth $<20 \mathrm{~m}$. However, Eh and TDS concentrations showed decreasing trends.

\subsection{Temporal variation in groundwater As}

Spatial variation in As concentration and water level fluctuation would result in temporal evolution of groundwater As in the study area. Temporal variation was evaluated in the locations of multilevel samplers. Arsenic concentration showed temporal variation at all locations. In BH01 and
BH04 with high As groundwater, there were slight increasing trends (Figure 2). Generally, groundwater had higher As concentration in irrigation seasons, in comparison with that in winter (November-April). Although deep groundwater was pumped for flood irrigation near $\mathrm{BH} 01$, and surface water was used for flood irrigation near BH04, irrigation return recharged shallow groundwaters at both locations. The recharge may be associated with the increases in As concentrations.

The increasing trends were also found in groundwaters at depths of $15 \mathrm{~m}$ at $\mathrm{BH} 02$ and $\mathrm{BH} 03$. Most importantly, groundwater As at the $15 \mathrm{~m}$ depth of $\mathrm{BH} 02$ was around 20 $\mu \mathrm{g} / \mathrm{L}$ before June 2011, and increased to around $60 \mu \mathrm{g} / \mathrm{L}$ after July 2011, which is greater than $50 \mu \mathrm{g} / \mathrm{L}$ of Chinese Drinking Water Guideline Value in rural areas [36]. However, As concentration kept relatively constant at depths less than $10 \mathrm{~m}$, where low As groundwaters were present $(<10$ $\mu \mathrm{g} / \mathrm{L})$. At the $20 \mathrm{~m}$ depth of those sites, groundwater showed slight decreasing trends in As concentrations, exhibiting opposite variation trends to those at the depth of 15 m (Figure 2). However, groundwater Eh generally showed opposite variation trends to As variation.

Iron(II) showed different variation trends from As concentrations. In groundwaters with As concentrations less than $50 \mu \mathrm{g} / \mathrm{L}$ at $\mathrm{BH} 02$ and $\mathrm{BH} 03, \mathrm{Fe}(\mathrm{II})$ variations were in line with those in As variations. However, at depths of $20 \mathrm{~m}$ at $\mathrm{BH} 01, \mathrm{BH} 02$, and $\mathrm{BH} 04$, and of $15 \mathrm{~m}$ at $\mathrm{BH} 01, \mathrm{Fe}(\mathrm{II})$ had distinct variation trends from As.

\section{Discussion}

\subsection{Redox controls on groundwater As}

There was negative correlation between As and Eh (Figure 4(a)). Arsenic concentrations were generally high ( $>100$ $\mu \mathrm{g} / \mathrm{L}$ ) in reducing groundwaters with $\mathrm{Eh}<100 \mathrm{mV}$. Reducing conditions were the predominant factor controlling As mobilization in the aquifers, which was in agreement with others in the river deltas and inland basins [4-11]. Arsenic was believed to be mobilized into groundwater from aquifer sediments under reducing conditions via reductive dissolution of Fe(III) oxide minerals [37].

The opposite trends in Eh values and As concentrations along the flow path also supported that As was preferentially released in reducing conditions. Along the flow path, Fe concentration increased from the recharge area to BH01 due to the decrease in Eh values (Figure 3(b)). This process led to the release of As from sediments, which was evidenced by the increase in As concentration. With the gradual decrease in Eh values, relative high $\mathrm{S}^{2-}$ concentration was observed, demonstrating that $\mathrm{SO}_{4}^{2-}$ reduction took place between Well Nos.5 and 7. The decrease in As concentration observed between Well No.6 and $\mathrm{BH} 02$ was probably due to precipitation of Fe-sulfides [38]. Between BH02 and Well No.9, groundwater had relative high Eh values, leading 

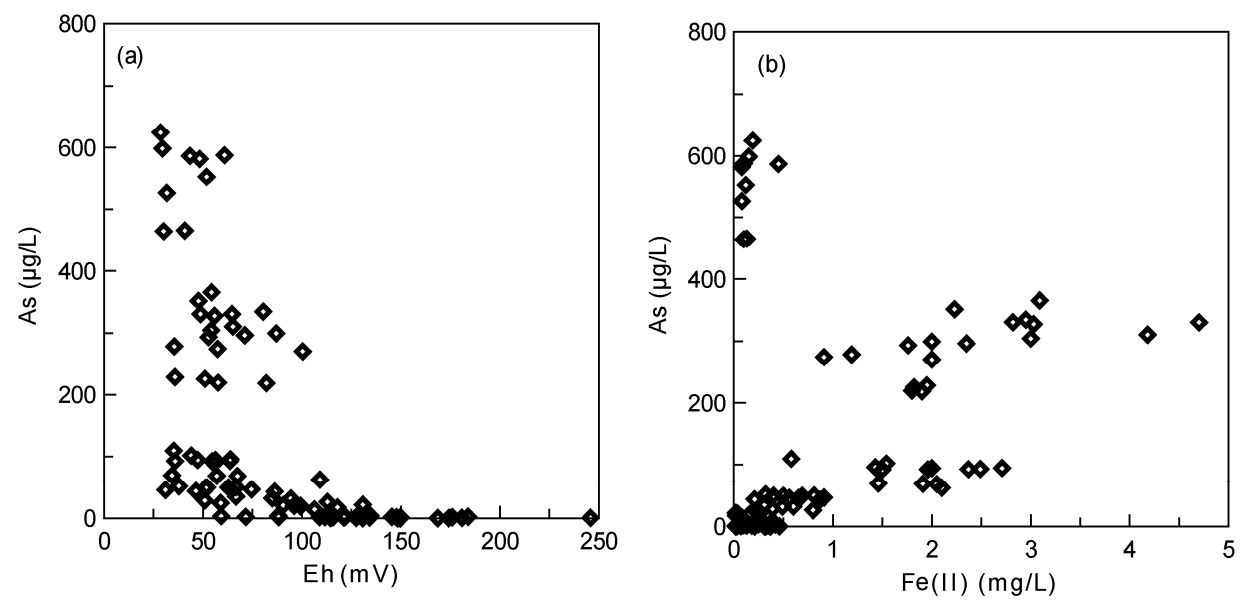

Figure 4 Plots of As concentration versus Eh value (a), and As concentration versus Fe(II) concentration (b).

to relative low concentrations of $\mathrm{Fe}, \mathrm{As}$ and $\mathrm{S}^{2-}$. Further down-gradient of Well No.9, Fe oxides was reduced due to low Eh values, causing the increase in As concentration in the groundwater.

Patterns of temporal and vertical variations in As concentration and Eh values also supported redox controls on As concentration. Temporal data showed that As concentration generally increased when Eh values decreased, and vise verse. In addition, groundwater As concentration increased and Eh values decreased with the increase in sampling depths in multilevel samplers.

\subsection{Effect of water level on groundwater As}

Effect of water levels on As concentration was dependent on irrigation practices and hydrogeological conditions. In $\mathrm{BH} 04$, where surface water was used for irrigation, As concentration was generally higher during the irrigation seasons with high groundwater levels (Figure 2(d)). This was consistent with observation that high groundwater level resulted in high As concentration [11], and that the lowest As concentration was associated with dry seasons [28]. This was also in line with the findings of Oinam et al. [39] conducted in West Bengal, showing the high As concentrations during monsoon due to the high water levels. The rise of groundwater level normally resulted from the recharge of irrigated water during irrigation seasons in the study area. Although the recharge of irrigated water did not cause dilution of groundwaters at depths of 15 and $25 \mathrm{~m}$ [11], flood irrigation resulted in more reducing conditions due to less oxygen dispersing into the aquifers [40]. Therefore, it was suggested that the rise in As concentrations during irrigation seasons with high water levels could attribute to the release of As from aquifer sediments in terms of local dissolution of iron oxyhydroxides and/or reductive desorption of $\mathrm{As}(\mathrm{V})$ as the conditions became more reducing in the study area.

In BH01, where deep groundwater was used for irrigation, As concentrations were generally higher during the irrigation seasons with low groundwater levels than those with the high groundwater levels (Figure 2(a)). Farooq et al. [29] also found an increase in As concentration during low groundwater level seasons. It may be related to the patchy horizontal distribution of As concentrations in shallow aquifers in the study area. Concentrations of shallow groundwater As ranged between 100 and $450 \mu \mathrm{g} / \mathrm{L}$ within the distance of $1 \mathrm{~km}$ from BH01 (data not shown). Groundwater pump resulted in lateral movement of groundwater with high As concentration, consequently contributing to the increase in As concentration during irrigation seasons with low water levels. It was observed that replenishment with high As groundwater increased As concentration in deep groundwater in Bengal basin [30,31].

In evaporation discharge areas of $\mathrm{BH} 02$ and $\mathrm{BH} 03$, where surface water was used for irrigation, dynamic behaviors were different at different depths. Groundwater at the depth of $15 \mathrm{~m}$ generally showed increasing trends, while at the depth of $20 \mathrm{~m}$ exhibited decreasing trends, especially during the summer (Figure 2(b) and (c)). During the summer, groundwater levels ranged between 2.0 and $3.0 \mathrm{~m}$ BLS at $\mathrm{BH} 02$, and between 1.5 and $2.5 \mathrm{~m}$ BLS at BH03, which were around $1.0 \mathrm{~m}$ higher than other seasons. The high water level promoted evaporation discharge in the arid area, which would enhance the recharge of groundwater from the upstream. Due to the presence of low As groundwater upstream, enhanced replenishment was expected to lead to the decrease in As concentration at depths around $20 \mathrm{~m}$. However, the recharge of underlying groundwater (around $20 \mathrm{~m}$ ) with high As concentration led to the increase in As concentration at the depth around $15 \mathrm{~m}$. Additionally, the reason for the relative constant As concentration at depths $<10$ $\mathrm{m}$ was the high Eh values of groundwaters, which would cause a significant portion of dissolved As to be adsorbed on $\mathrm{Fe}(\mathrm{III})$-bearing minerals in the shallowest aquifer sediments. Datta et al. [41] also observed a natural reactive barrier to scavenge groundwater As before it was discharged into river. 


\subsection{Roles of Fe mineral precipitations in groundwater} As

Although reductive dissolution of $\mathrm{Fe}(\mathrm{III})$ oxides was believed to result in As release from sediments, it was observed that As concentration was poorly correlated with $\mathrm{Fe}(\mathrm{II})$ concentration in studied groundwater (Figure 4(b)). Data of temporal variations also showed the incompatible trends between As and $\mathrm{Fe}(\mathrm{II})$ in groundwaters with As $>100$ $\mu \mathrm{g} / \mathrm{L}$. Typically, low $\mathrm{Fe}(\mathrm{II})$ was detected in groundwater of BH04 under reducing conditions, where high As concentrations occurred. Therefore, other processes involving Fe cycling were expected to control groundwater As. Calculation of saturation indices (SI), by using hydrogeochemical code PHREEQC [42], showed that all of groundwaters were oversaturated with respect to pyrite and mostly saturated with respect to siderite (Figure 5). Precipitation of Fe(II) minerals (including siderite and pyrite) was expected to attribute to these incompatible trends. There was a negative correlation between As concentration and $\mathrm{SI}_{\text {siderite }}$ in groundwaters with As concentrations $>100 \mu \mathrm{g} / \mathrm{L}$ and Eh values $<100 \mathrm{mV}$ (Figure 5(a)), indicating higher As concentrations in groundwater with lower $\mathrm{SI}_{\text {siderite }}$ values. It was suggested that siderite precipitation would eliminate As from groundwaters. Previous studies had found that siderite hosts substantial As in both laboratory conditions $[43,44]$ and the field site $[45,46]$. In addition, groundwaters with high $\mathrm{SI}_{\text {pyrite }}$ values generally had low As concentrations, although most $\mathrm{SI}_{\text {pyrite }}$ values ranged between 15 and 18 (Figure 5(b)). It may imply that pyrite precipitation decreased groundwater As concentration. The formation of authigenic pyrite was proposed to be the sink of groundwater As by coprecipitation in reducing conditions [47-49].

Control of pyrite precipitation in groundwater As was also supported by significant variations in dissolved $\mathrm{Fe}, \mathrm{S}^{2-}$ and As concentrations between near neighboring wells. From Well No. 6 to BH01 (at $20 \mathrm{~m}$ depth), a drastic increase in Fe concentration, accompanied by an evident de- crease in $\mathrm{S}^{2-}$ concentration (Figure 3(b)), was expected to be the results of both $\mathrm{Fe}$ oxide reduction and Fe-sulfide precipitation. Although $\mathrm{Fe}$ oxide reduction was expected to release As, Fe-sulfide precipitation would contribute to the decrease in As concentration from 360 to $328 \mu \mathrm{g} / \mathrm{L}$. Between Well No.10 and BH04, the main process controlling As and Fe cycling was pyrite precipitation due to the decreases in both $\mathrm{Fe}$ and $\mathrm{S}^{2-}$ concentrations, which resulted in a greater decrease in As concentration (from 666 to 514 $\mu \mathrm{g} / \mathrm{L})$, in comparison with that between Well No.6 to BH01.

\section{Conclusion}

In the study area, higher As concentrations being accompanied with lower Eh values and higher Fe concentration indicated that As was mobilized via reductive dissolution of Fe oxides. Spatial variation in groundwater As was observed approximately along the flow path. Groundwater As concentration generally showed increasing trends along the flow path with low As concentration in the recharge area $(<10 \mu \mathrm{g} / \mathrm{L})$, although it was affected by groundwater evaporation and pyrite and siderite precipitation. In evaporation discharge area, shallow groundwater As concentrations were generally lower $(<100 \mu \mathrm{g} / \mathrm{L})$ than those upstream and downstream due to relative higher Eh values. Additionally, in groundwaters being saturated with respect to siderite and pyrite, siderite and pyrite precipitations were expected to retain groundwater As and decrease As concentration, which was evidenced by the negative correlations between As concentration and $\mathrm{SI}_{\text {pyrite }}$ (or $\mathrm{SI}_{\text {siderite }}$ ). Temporal variation showed different trends in different locations. The variations would be related to replenishment of high/low As groundwater upstream for the increase/decrease in As concentrations. Results also showed that enhanced evaporation in the discharge areas due to high water level, increasing the recharge of underlying groundwater to $15 \mathrm{~m}$ depth aquifer, led to the increase trends in groundwater As concentrations
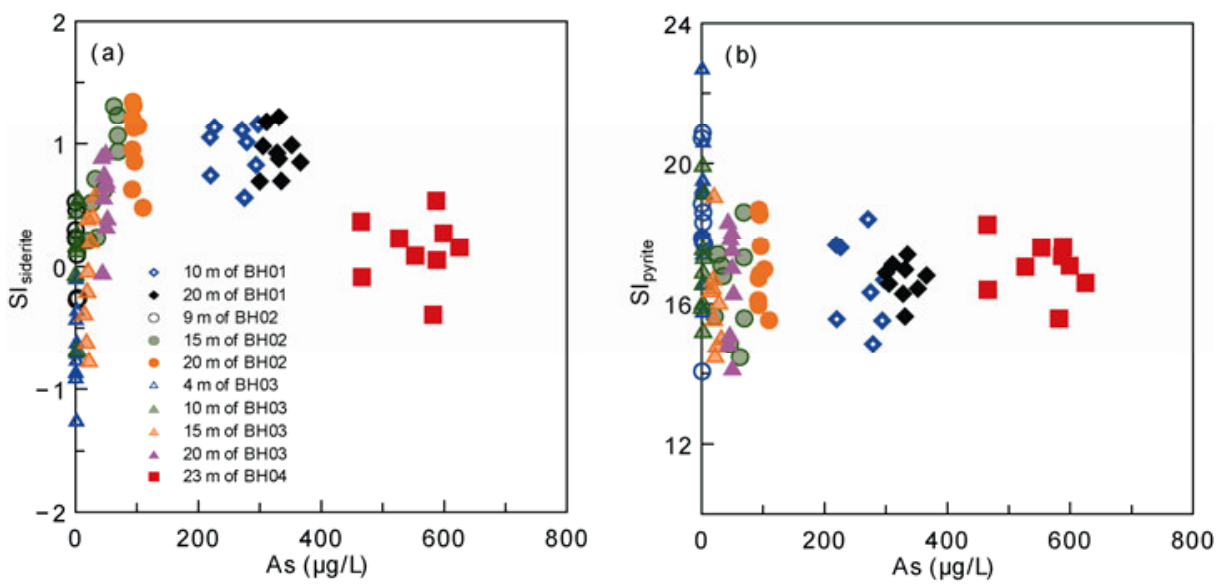

Figure 5 Plots of $\mathrm{SI}_{\text {siderite }}$ versus As concentration (a), and $\mathrm{SI}_{\text {pyrite }}$ versus As concentration (b). 
at depth around $15 \mathrm{~m}$ of $\mathrm{BH} 02$ and $\mathrm{BH} 03$. Temporal variation required the routine monitoring of groundwater As in the As-affected areas.

This work was supported by the National Natural Science Foundation of China (41222020 and 41172224), the Program for New Century Excellent Talents in University (NCET-07-0770), the Chinese Universities Scientific Fund (2010ZD04), and the Fok Ying-Tung Education Foundation, China (131017).

1 Nordstrom D K. Worldwide occurrences of arsenic in ground water. Science, 2002, 296: 2143-2144

2 Nickson R, McArthur J, Burgess W, et al. Arsenic poisoning of Bangladesh groundwater. Nature, 1998, 395: 338

3 Harvey C F. Poisoned waters traced to source. Nature, 2008, 454: 415-416

4 Polizzotto M L, Kocar B D, Benner S G, et al. Near-surface wetland sediments as a source of arsenic release to ground water in Asia. Nature, 2008, 454: 505-508

5 Fendorf S, Michael H A, van Geen A. Spatial and temporal variations of groundwater arsenic in South and Southeast Asia. Science, 2010, 328: 1123-1127

6 Guo H M, Yang S Z, Tang X H, et al. Groundwater geochemistry and its implications for arsenic mobilization in shallow aquifers of the Hetao Basin, Inner Mongolia. Sci Total Environ, 2008, 393: 131-144

7 Guo H M, Zhang B, Li Y, et al. Hydrogeological and biogeochemical constrains of As mobilization in shallow aquifers from the Hetao basin, Inner Mongolia. Environ Pollut, 2011, 159: 876-883

8 Guo H M, Zhang Y, Xing L N, et al. Spatial variation in arsenic and fluoride concentrations of shallow groundwater from the Shahai town of the Hetao basin, Inner Mongolia. Appl Geochem, 2012, 27: 21872196

9 Luo T, Hu S, Cui J L, et al. Comparison of arsenic geochemical evolution in the Datong Basin (Shanxi) and Hetao Basin (Inner Mongolia), China. Appl Geochem, 2012, 27: 2315-2323

10 Deng Y, Wang Y, Ma T. Isotope and minor element geochemistry of high arsenic groundwater from Hangjinhouqi, the Hetao plain, Inner Mongolia. Appl Geochem, 2009, 24: 587-599

11 Guo H M, Zhang Y, Jia Y F, et al. Dynamic behaviors of water levels and arsenic concentration in shallow groundwater from the Hetao Basin, Inner Mongolia. J Geochem Explor, 2012, doi: 10.1016/j. gexplo.2012.06.010

12 Ravenscroft P, Brammer H, Richards K S. Arsenic Pollution: A Global Synthesis. Singapore: Wiley-Blackwell, 2009. 1-114

13 van Geen A, Zheng Y, Versteeg R, et al. Spatial variability of arsenic in 6000 tube wells in a $25 \mathrm{~km}^{2}$ area of Bangladesh. Water Resour Res, 2003, 39: 1140

14 Berg M, Trang P T K, Stengel C, et al. Hydrological and sedimentary controls leading to arsenic contamination of groundwater in the Hanoi area, Vietnam: The impact of iron-arsenic ratios, peat, river bank deposits, and excessive groundwater abstraction. Chem Geol, 2008, 249: 91-112

15 Xie X J, Wang Y X, Su C L, et al. Influence of irrigation practices on arsenic mobilization: Evidence from isotope composition and $\mathrm{Cl} / \mathrm{Br}$ ratios in groundwater from Datong Basin, northern China. J Hydrol, 2012, 424-425: 37-47

16 Harvey C F, Swartz C H, Badruzzaman A B M, et al. Arsenic mobility and groundwater extraction in Bangladesh. Science, 2002, 298: 1602-1606

17 Ravenscroft P, McArthur J M, Hoque B A. Geochemical and palaeohydrological controls on pollution of groundwater by arsenic. In: Chappell W R, Abernathy C O, Calderon R, eds. Arsenic Exposure and Health Effects IV. Oxford: Elsevier, 2001. 53-78

18 McArthur J M, Banerjee D M, Hudson-Edwards K A, et al. Natural organic matter in sedimentary basins and its relation to arsenic in anoxic ground water: The example of West Bengal and its worldwide implications. Appl Geochem, 2004, 19: 1255-1293

19 Guo H M, Yang S Z, Tang X H, et al. Distribution of high As groundwater and mechanisms of As mobilization in shallow aquifers from the Hetao basin, Inner Mongolia (in Chinese). Hydrogeol Eng Geol, 2008, 35(Suppl): 92-99

20 Aziz Z, van Geen A, Stute M, et al. Impact of local recharge on arsenic concentrations in shallow aquifers inferred from the electromagnetic conductivity of soils in Araihazar, Bangladesh. Water Resour Res, 2008, 44: W07416

21 Nath B, Mallik S B, Stüben D, et al. Electrical resistivity investigation of the arsenic affected alluvial aquifers in West Bengal, India: Usefulness in identifying the areas of low and high groundwater arsenic. Environ Earth Sci, 2010, 60: 873-884

22 McArthur J M, Ravenscroft P, Banerjee D M, et al. How paleosols influence groundwater flow and arsenic pollution: A model from the Bengal Basin and its worldwide implication. Water Resour Res, 2008, 44: W11411

23 McArthur J M, Nath B, Banerjee D M, et al. Palaeosol control on groundwater flow and pollutant distribution: the example of arsenic. Environ Sci Technol, 2011, 45: 1376-1383

24 Hoque M A, McArthur J M, Sikdar P K. The palaeosol model of arsenic pollution of groundwater tested along a $32 \mathrm{~km}$ traverse across West Bengal, India. Sci Total Environ, 2012, 431: 157-165

25 Stute M, Zheng Y, Schlosser P, et al. Hydrological control of As concentrations in Bangladesh Groundwater. Water Resour Res, 2007, 43: W09417

26 Weinman B, Goodbred Jr S L, Zheng Y, et al. Contributions of floodplain stratigraphy and evolution to the spatial patterns of groundwater arsenic in Araihazar, Bangladesh. Geol Soc Am Bull, 2008, doi: 10.1130/B26209.1

27 van Geen A, Zheng Y, Goodbred Jr S L, et al. Flushing history as a hydrogeological control on the regional distribution of arsenic in shallow groundwater of the Bengal basin. Environm Sci Technol, 2008, 42: 2283-2288

28 Cheng Z, van Geen A, Sqddique A A, et al. Limited temporal variability of arsenic concentrations in 20 wells monitored for 3 years in Araihazar, Bangladesh. Environ Sci Technol, 2005. 39: 4759-4766

29 Farooq S H, Chandrasekharam D, Norra S, et al. Temporal variations in arsenic concentration in the groundwater of Murshidabad District, West Bengal, India. Environ Earth Sci, 2011, 62: 223-232

30 Radloff K A, Zheng Y, Michael H A, et al. Arsenic migration to deep groundwater in Bangladesh influenced by adsorption and water demand. Nat Geosci, 2011, 4: 793-798

31 Burgess W G, Hoque M A, Michael H A, et al. Vulnerability of deep groundwater in the bengal aquifer system to contamination by arsenic. Nat Geosci, 2011, 3: 83-87

32 Dhar R K, Zheng Y, Stute M, et al. Temporal variability of groundwater chemistry in shallow and deep aquifers of Araihazar, Bangladesh. J Contam Hydrol, 2008 , 99: 97-111

33 Guo H M, Tang X H, Yang S Z, et al. Effect of indigenous bacteria on geochemical behavior of arsenic in aquifer sediments from the Hetao Basin, Inner Mongolia: Evidence from sediment incubation. Appl Geochem, 2008, 23: 3267-3277

34 Guo H M, Zhang B, Zhang Y. Control of organic colloids on arsenic partition and transport in high arsenic groundwaters in the Hetao basin, Inner Mongolia. Appl Geochem, 2011, 26: 360-370

35 Guo H M, Zhang B, Wang G C, et al. Geochemical controls on arsenic and rare earth elements approximately along a groundwater flow path in the shallow aquifer of the Hetao basin, Inner Mongolia. Chem Geol, 2010, 270: 117-125

36 Ministry of Health of PR China. Standard for drinking water quality (in Chinese), GB5749-2006, 2006

37 Islam F S, Gault A G, Boothman C, et al. Role of metal-reducing bacteria in arsenic release from Bengal delta sediments. Nature, 2004, 430: 68-71

38 Kim K J, Moon J T, Kim S H, et al. Importance of surface geologic condition in regulating As concentration of groundwater in the alluvial plain. Chemosphere, 2009, 77: 478-484 
39 Oinam J D, Ramanathan A, Linda A, et al. A study of arsenic, iron and other dissolved ion variations in the groundwater of Bishnupur district, Manipur, India. Environ Earth Sci, 2011, 62: 1183-1195

40 Williams M D, Oostrom M. Oxygenation of anoxic water in a fluctuating water table system: An experimental and numerical study. J Hydrol, 2000, 230: 70-85

41 Datta S, Mailloux B, Jung H B, et al. Redox trapping of arsenic during groundwater discharge in sediments from the Meghna riverbank in Bangladesh. Proc Natl Acad Sci USA, 2009, 106: 16930-16935

42 Parkhurst D L, Appelo C A J. User's guide to PHREEQC (version 2)-A computer program for speciation, batch-reaction, one dimensional transport and inverse geochemical calculation. USGS Water Resources Investigation Report 99-4259, Denver: U.S. Geological Survey, 1999

43 Guo H M, Li Y, Zhao K, et al. Removal of arsenite by synthetic siderite: Behaviors and mechanisms. J Hazard Mater, 2011, 186: 1847-1854

44 Guo H M, Ren Y, Liu Q, et al. Enhancement of arsenic adsorption during mineral transformation from siderite to goethite: Mechanism and application. Environ Sci Technol, 2013, 47: 1009-1016

45 Sengupta M K, Mukherjee A, Hossain M A, et al. Groundwater arsenic contamination in the Ganga-Padma-Meghna-Brahmaputra plain of India and Bangladesh. Arch Environ Health, 2003, 58: 701-702

46 Kim K J, Park S M, Kim J, et al. Arsenic concentration in porewater of an alkaline coal ash disposal site: Roles of siderite precipitation/ dissolution and soil cover. Chemosphere, 2009, 77: 222-227

47 Lowers H A, Breit G N, Foster A L, et al. Arsenic incorporation into authigenic pyrite, Bengal basin sediment, Bangladesh. Geochim Cosmochim Acta, 2007, 71: 2699-2717

48 Reza A H M S, Jean J S, Yang H J, et al. Occurrence of arsenic in core sediments and groundwater in the Chapai-Nawabganj District, northwestern Bangladesh. Water Res, 2010, 44: 2021-2037

49 Wang Y, Jiao J J, Cherry J A. Occurrence and geochemical behavior of arsenic in a coastal aquifer-aquitard system of the Pearl River Delta, China. Sci Total Environ, 2012, 427-428: 286-297

Open Access This article is distributed under the terms of the Creative Commons Attribution License which permits any use, distribution, and reproduction in any medium, provided the original author(s) and source are credited. 